\begin{tabular}{|l|l|l||}
\hline \multicolumn{2}{|c|}{ PublisherInfo } \\
\hline \hline PublisherName & $:$ & BioMed Central \\
\hline \hline PublisherLocation & $:$ & London \\
\hline \hline PublisherImprintName & $:$ & BioMed Central \\
\hline \hline
\end{tabular}

\title{
p38 MAPK required for IL-12 function
}

\begin{tabular}{||l|l||l||}
\hline \multicolumn{2}{|c|}{ ArticleInfo } \\
\hline \hline ArticleID & $:$ & 84 \\
\hline \hline ArticleDOI & $:$ & $10.1186 /$ ar-2001-68221 \\
\hline \hline ArticleCitationID & $:$ & 68221 \\
\hline \hline ArticleSequenceNumber & $:$ & 41 \\
\hline \hline ArticleCategory & $:$ & Paper Report \\
\hline \hline ArticleFirstPage & $:$ & 1 \\
\hline \hline ArticleLastPage & $:$ & 3 \\
\hline \hline & & RegistrationDate $: 2001-7-26$ \\
ArticleHistory & $:$ & Received \\
& Accepted $\quad$ 2001-3-8 \\
\hline \hline ArticleCopyright & $:$ & Biomed Central Ltd2001-7-26 \\
\hline \hline ArticleGrants & $:$ & \\
\hline \hline
\end{tabular}




\begin{tabular}{|l|l|l|}
\hline ArticleContext & $:$ & 130753311 \\
\hline
\end{tabular}

Athanasios Mavropoulos, ${ }^{\text {Aff1 }}$

Aff1 The Kennedy Institute of Rheumatology, London, UK

Keywords

IL-12, MAPK, T cells, Th differentiation

\section{Context}

The differentiation of $\mathrm{T}$ cells into $\mathrm{T}$ helper (Th) effector cells is an essential component of adaptive immune responses, but is of particular relevance for understanding the pathogenesis of autoimmunity and chronic inflammatory diseases. As interleukin (IL)-12 has been shown to promote the differentiation of Th1 cells, this study set out to explore signalling pathways downstream of IL-12 receptor engagement that are required for interferon (IFN)-? production by activated T cells. The binding of IL-12 to its receptor has been shown to activate JAK kinases, resulting in the recruitment of Stat4; this study, however, investigated the role of mitogen-activation protein kinase (MAPK) activity in IL-12 signalling during Th1 cell differentiation.

\section{Significant findings}

The activation of MKK $3 / 6$ and p38, but not of ERK or JNK MAPK, is required for the induction of IFN-g mRNA and protein production following IL-12 stimulation of activated T cells and Th1 cells. Although Stat4 is critical for IFN-? production by T cells, the study demonstrates that the p38 pathway is activated independently of this particular transcription factor. In vitro kinase assays, using ATF-2 as substrate, as well as the p38 inhibitor SB203580 were used to support the data, although in some experiments high concentrations $(10 \mathrm{mM})$ were used.

\section{Comments}


It is becoming increasingly clear that selective blockade of MAPK pathways can profoundly influence the maturation and differentiation of effector T cells. Consequently, these pathways provide potential therapeutic targets in chronic inflammatory diseases. This report provides further evidence to substantiate this view. Since the inhibition of JNK activity at high concentrations of SB203580 has been documented, and ATF-2 is also a substrate for JNK, a role for this MAPK has not been completely excluded in this study. This is especially important given that in mice deficient in JNKs 1 and 2 Th1 differentiation is impaired. This study focused only on the possible transcriptional regulation of IFN-? by $\mathrm{p} 38 \mathrm{MAPK}$. No reference was made to the possibility that post-transcriptional mechanisms at the level of mRNA stability and nuclear transport could contribute, at least in part, to the observations reported.

\section{Methods}

T-cell culture, northern blotting, ELISA, immunoprecipitation, in vitro kinase assays

\section{Additional information}

\section{References}

1. Zhang S, Kaplan MH: The p38 mitogen activated protein kinase is required for IL-12 induced IFN-? expression. J Immunol. 2000, 165: 1374-1380.

This PDF file was created after publication. 